\title{
Exploring Classroom Willingness to Communicate: The Role of Motivating Future L2 Selves
}

\author{
Siying Shen ${ }^{*}$ \\ Fuzhou University of International Studies \\ and Trade, CHINA
}

\author{
Diana Mazgutova \\ University of Leeds, UK
}

\author{
Gareth McCray \\ Keele University, UK
}

Received: August 15, 2020 - Revised: October 10, 2020 - Accepted: November 2, 2020

\begin{abstract}
This study investigated the link between future L2 selves and Willingness to Communicate (WTC) in the classroom in the UK university context. We applied a mixed methods approach to collect data from 121 Chinese overseas students where a questionnaire was used before semi-structured interviews were conducted with six participants. Two key quantitative findings were: 1) There is a strong positive correlation between ideal L2 self and classroom WTC; 2) A student's major moderates the relationship between the ought-to L2 self and classroom WTC. Students from non-English-related majors had a greater influence of ought-to L2 self on their WTC in the classroom, while ought-to L2 self does not seem to affect the WTC of English-related majors in the classroom. Follow-up interviews triangulated the quantitative findings with further illustrations in terms of the role of future L2 selves in stimulating WTC in the classroom and the potential differences between students with different academic backgrounds.
\end{abstract}

Keywords: Willingness to communicate in the classroom, ideal L2 self, ought-to L2 self, English-related majors, non-English related majors.

To cite this article: Shen, S., Mazgutova, D., \& McCray, G. (2020). Exploring classroom willingness to communicate: The role of motivating future L2 selves. International Journal of Educational Methodology, 6(4), 729-743. https://doi.org/10.12973/ijem.6.4.729

\section{Introduction}

Showing willingness to communicate with the instructor and peers in the classroom is often seen as a sign of an engaged learner. Nevertheless, it is sometimes uncomfortable for students to actively participate in classroom activities requiring intensive language use in a second language (L2). Unwillingness to communicate, seems to be a noticeable feature of some groups of international students in the academic context. Chinese university students are now one of the major groups of overseas students in the UK, but despite their proficiency in English overall they are often observed as reticent L2 speakers in class (Xie, 2010). The feature of this learner group has generated much discussion about the causes of their perceived low levels of L2 Willingness to Communicate (WTC) from the perspectives of both cultural features and individual differences. Earlier studies tended to discuss the issue from the first perspective, attributing their reluctance to speak in English to the Chinese traditional submissive learning style (Wen \& Clément, 2003) or collective cultural values (Peng \& Woodrow, 2010). In contrast, recent research over the past decade has appeared to view the culture-oriented viewpoint as over-generalized (Shao \& Gao, 2016) and has analysed the unwillingness to communicate among Chinese students in English medium language classrooms by focusing on the individual characteristics of L2 learners (Pawlak \& Mystkowka-Wiertelak, 2015).

Much research has focused on how L2 motivation is related to L2 WTC - given the fact that a high level of motivation on the target language often stimulates desire to communicate with the target population (MacIntyre et al., 1998). In the past two decades, empirical studies in various contexts have investigated and found associations between L2 WTC and various conceptualizations of motivation, such as integrative motivation (Peng, 2007) and the L2 Motivational System (L2MSS) (Lee \& Lee, 2020). Particularly, the motivational force of ideal L2 self in L2MSS tends to be significant both in WTC-related research (e.g., Öz et al., 2015) and in studies concerning other motivated learning behaviours (e.g., Nakamura, 2019). However, the motivational impetus of ought-to L2 self, a less studied element from L2MSS, does not seem to be as strong (Csizér \& Lukács, 2010) or as clear-cut (Lamb, 2007) as that of ideal L2 self. Further in-depth

\footnotetext{
* Corresponding author:

Siying Shen, School of Foreign Languages, Fuzhou University of International Studies and Trade, Fuzhou, China. $\square$ shensiying@fzfu.edu.cn
} 
investigation, therefore, may be needed to understand the role of both ideal L2 self and ought-to L2 self as motivating future L2 selves in the learning behaviours of L2 learners.

\section{Literature Review}

\section{Willingness to Communicate}

The concept of WTC, originally studied in the first language context, had been transposed to and studied in the L2 context (MacIntyre et al., 1998). L2 WTC is defined as "a readiness to enter into discourse at a particular time with a specific person or persons, using an L2” (MacIntyre et al., 1998, p. 547). Numerous studies have addressed L2 WTC in differing learner groups (e.g., Korean students: Kang, 2005; Chinese students: Peng, 2007; Canadian students: MacIntyre \& Legatto, 2011; Iranian students: Cameron, 2015; Pakistani students: Bukhari \& Cheng, 2017). WTC in the L2 context is regarded as a complex phenomenon influenced by both learner-internal (e.g., motivation, proficiency, etc.) and learner-external (e.g., learning environment, teaching style, etc.) factors (Shao \& Gao, 2016). For L2 learners, L2 WTC is thought to be an important element in the milieu of variables which interact in complex ways to promote their L2 learning. Students with high levels of L2 WTC are usually believed more successful learners than those with lower levels (MacIntyre et al., 2003). One commonly applied conceptualization of L2 WTC is the heuristic model proposed by MacIntyre et al. (1998). This model delineates several potential influences on a learner's L2 WTC, including those which are stable (e.g., a learner's personality, social situation) and those which are situational (e.g., a person's desire to communicate, state communicative self-confidence). The spread of this model has led to numerous empirical studies investigating WTC through this prism especially among learner groups with less active classroom participation (e.g., Khajavy et al., 2016; Lin, 2019; Yashima et al., 2018).

\section{Willingness to Communicate in the Chinese Learner Context}

Chinese learners of English are often the subject of L2 WTC research due to their perceived low levels of oral participation in the class (e.g., Peng, 2019; Peng et al., 2017). As stated above, their low WTC is traditionally explained from a cultural perspective, where Confucian values (e.g., face-protection tendency, respect for authority, modesty, collectivism) are influential on their language learning (Xie, 2010). For instance, Wen and Clément (2003) found that Chinese students tend to rely heavily on the instructions of teachers to orientate their learning and are not used to voicing opinions. Recent research, however, has questioned this cultural explanation of low classroom involvement. Bao (2014) and Zhu (2016) argued that the cultural interpretations of low WTC seem overgeneralized, as they neglect the individual differences underneath learning behaviours, such as students' various thinking styles and learning preferences. Similarly, Shao and Gao (2016) emphasized the role of individual conditions of Asian EFL learners in their WTC. Shifting the focus onto individual differences in learning, this recent perspective suggests that though low WTC might stem from different cultural backgrounds, it alone cannot explain the perception of low levels of classroom WTC among Chinese students and other self-related factors might be at play.

\section{L2 Motivation and Future L2 Selves}

L2 motivation is commonly considered a precursor of L2 WTC (Boo et al., 2015). In the field of L2 motivation, Dörnyei's (2009) L2 Motivational Self System (L2MSS) is a contemporary conceptualization of L2 motivation that has been applied widely over the last decade. The two 'self'-related concepts in this model are ideal L2 self and ought-to L2 self. Ideal L2 self refers to a person's ideal self-image in an L2 (Dörnyei, 2009), for example, a learner who is motivated to work hard to fulfil the strong internal desire (an ideal self-image) to speak like a native-like English speaker. Ought-to L2 self, on the other hand, involves meeting expectations from significant others (family, friends, colleagues, etc.) and avoiding negative L2 learning outcomes (ibid.). For instance, a student may learn English to pass an important exam and gain parental approval and, thus, avoid conflict. The two constructs were based upon the concept of future L2 selves, defined as a future-directed element of one's self-concept (Oyserman \& James, 2009). Since the motivating future L2 selves (i.e., ideal and ought-to L2 selves in this study) enable L2 learners to visualize themselves as proficient L2 users in the future, they can be understood as "long-term personal motivational trajectories", through which people might be motivated to make efforts to reduce the discrepancy between their current situations and future aspirations (Ushioda, 2011, p. 203).

The motivation generated by ideal L2 self and ought-to L2 self, however, is thought to interact with contextual factors like age, culture, gender, etc. (see e.g., Fryer \& Roger, 2018; Lamb, 2012; Papi, 2010). In the Iranian EFL context, Papi and Teimouri (2012) found that ought-to L2 self becomes less influential with an increase in age. Meanwhile, Csizér and Kormos (2009) found that the image of ideal L2 self is more vivid in Hungarian university students than high school counterparts. Since ideal L2 self indicates what someone 'would like' to become, it is usually regarded as a very strong motivator and internal force for achieving personal L2 related goals (Ushioda \& Dörnyei, 2009). In comparison, oughtto L2 self tends to concern influences outside oneself, and thus is likely to represent a preventative force by which learners are driven to make efforts in L2 learning to avoid negative outcomes (ibid.). Overall, studies conducted in different contextual situations have shown how individual differences may affect the strength of the motivation from future L2 selves in different manners. 
Besides contextual factors, ought-to and ideal L2 self may interact with each other to result in differential motivational outcomes. Dörnyei and Ushioda (2011) claimed that if there exists a large discrepancy between ideal L2 self and oughtto L2 self, their motivational influence might be reduced. In other words, if learners' own ideal language goals differ from or even conflict with what they are expected by others, they are likely less motivated to put effort into their learning. The relationship between ideal L2 self and ought-to L2 self reflects possible interconnections between future L2 selves which L2MSS does not fully explain. In fact, the original theory of future L2 selves introduced by Higgins (1987) indicates two dimensions: 'own' standpoint (from internal) and 'other' standpoint (from external). The two standpoints suggest ideal L2 self and ought-to L2 self can both have two layers, which are ideal L2 self/own, ideal L2 self/other, ought-to L2 self/own and ought-to L2/other (Teimouri, 2017). Specifically, whereas the 'own' dimension is in relation to what people associate with either their own wishes (ideal L2 self/own) or internalized goals from outside influence (ought-to L2 self/own), the 'other' dimension indicates what others want you to have (ideal L2 self/other) or what others think you should possess (ought-to L2 self/other) (Lanvers, 2016). This further categorization presents a fuller picture of future L2 selves where both the 'own' and 'other' dimensions within them are highlighted. It also indicates that ideal L2 self and ought-to L2 self should not be studied in isolation; rather it should be acknowledged that they form part of a system of influences which have an impact on language learning performance.

\section{Future L2 Selves in the Chinese Learner Context}

Recent decades have seen a huge rise in the number of Chinese EFL and ESL learners around the globe. A substantial amount of research on this group has examined the motivational effectiveness of future L2 selves, revealing the different potential influences on their L2 selves during the language learning journey. For instance, Magid (2009) conducted a study among middle school and university level Chinese learners, which found that for university students in particular, the role of family is crucial in encouraging the motivational effects from their future L2 selves. Specifically, a participant claimed that his purpose for learning English was to "get a promotion for my [his] parents' welfare" (ibid., p. 82). The significance of family influence is consistent with Taguchi et al. (2009). Additionally, degree subject, according to You et al. (2016), can greatly influence the ideal L2 self of university students, in the sense that the closer a student's course is related to English (i.e., English majors), the stronger the ideal L2 self is. This highlights the potential impact of university major can have on students' language selves, which may stimulate their learning behaviour differently.

\section{Future L2 Selves and Willingness to Communicate}

According to Dörnyei (2005), L2 WTC is interwoven with various psychological and linguistic factors of L2 learning. Given L2 motivation is one of the important factors that influences L2 WTC (MacIntyre et al. 1998), research has looked into their association where the close relationship between future L2 selves and L2 WTC has been identified in various contexts (e.g., Lee \& Lee, 2020; Papi, 2010; Yue, 2014). In some cases, the relationship is direct, and in others it is mediated through other salient variables. Regarding a direct link, Munezane (2013) found ideal L2 self was a significant predicator to L2 WTC in a Japanese university context. This result is in line with Öz (2016) and Öz et al. (2015) who found the same association among Turkish EFL learners. As regards salient variables mediating the link between the two L2 selves and WTC, Papi (2010) demonstrates that the two L2 selves can affect WTC in the classroom mediated by L2 anxiety. In other words, the levels of L2 self-influenced anxiety may in turn influence motivated learning behaviours. Specifically, a stronger ideal L2 self might reduce anxiety whereas a stronger ought-to L2 self was found to stimulate anxiety. Peng (2015) found the similar relationship between WTC and the two L2 selves.

In addition, future L2 selves have been found to be associated with one another in empirical studies. Both Peng (2015) and Csizér and Kormos (2009) pointed out the relationship between the two selves in which ought-to L2 self can directly influence ideal L2 self. Furthermore, Magid (2009) argued that with the influence from family, students' ideal L2 self may contain some internalized parts of their ought-to L2 self. For example, if a family has an expectation to a child from a young age (what others wants the person to do), it may gradually grow into the child's domain of ideal L2 self (what the person genuinely wants to do). It shows that external influence can greatly contribute to the internalization of a student's ought-to L2 self into the ideal L2 self. This also reflects the concept of 'own' and 'other' dimensions in future L2 selves, which was discussed previously, as the process of internalization might start from one's domain of ought-to L2 self/other to ought-to L2 self/own. The probable complexity between future L2 selves tends to add a new layer to L2 motivation research and therefore the research on motivated learning behaviours like WTC.

\section{Research Questions}

Given the current large number of Chinese students studying in foreign universities (Su \& Harrison, 2016), there is relatively limited literature on the association between future L2 selves and L2 WTC in the Chinese university level context. A richer understanding of the relationship between these two factors and how they combine to influence learning are needed to better inform theory and practice. Our study, therefore, will investigate into the relationship between L2 WTC and future L2 selves in the UK university context. The following research questions were formulated in the current study: 
1. To what extent are ideal L2 self and ought-to L2 self of Chinese postgraduate students studying in the UK associated with WTC in the English classroom?

2. Does the major for which the participant is studying moderate the relationship between ideal L2 self/ought-to L2 self and WTC in the English classroom among Chinese postgraduate students?

\section{Methods}

\section{Participants}

The study involved 121 Chinese postgraduate students recruited from five universities across the UK. All participants had achieved a Bachelor's degree in China and their English language proficiency varied between B2 to C1 according to Common European Framework of Reference (CEFR) (Council of Europe, 2001). For most, studying in the UK was their first learning experience in an English-speaking country. In this study, we categorized their majors as English majors (e.g., TESOL, English Translation) and non-English majors (e.g., Business Studies, Data Science), depending on whether or not their programme appeared to be closely connected with the learning or the application of the English language. Table 1 illustrates more detailed information about the participants.

Table 1. Participant information ( $N=121)$

\begin{tabular}{lll}
\hline \multirow{2}{*}{ Gender } & & $\mathbf{N}$ \\
\hline Age & Male & 17 \\
\hline \multirow{2}{*}{ Major } & Female & 104 \\
\hline \multirow{2}{*}{ Length of stay } & Mean (SD) & $23.35(1.24)$ \\
& English majors & 57 \\
IELTS & Non-English majors & 64 \\
(CEFR) & One year & 95 \\
\hline
\end{tabular}

\section{Procedures}

The research was conducted using a mixed methods approach, notably, in the analysis of individual differences in WTCrelated studies. We used a sequential research design by applying quantitative methods followed by qualitative methods. In other words, while the quantitative phase tends to have more weight in identifying the relationship between the variables, the follow-up qualitative aspect was for the purpose of triangulation (Riazi \& Candlin, 2014). Specifically, quantitative data were gathered by questionnaire. The questionnaire was sent via email, and participants had the option of competing the questionnaire in either Chinese or English. The data were later analysed using the statistical package R. The qualitative data were generated with the aid of semi-structured interviews, which were conducted on six participants to triangulate the findings from the quantitative study and gain a deeper understanding of the issues. Before the interviews, the participants were asked to indicate their preference of the language to be used in the interview and five out of six participants chose their first language Mandarin Chinese.

\section{Instruments}

As alluded to above, the two data collection instruments used in the study were a questionnaire and a semi-structured interview. The questionnaire was anonymous, comprising participants' background information and scales to measure WTC in the classroom, ideal L2 self and ought-to L2 self (See Appendix A). The semi-structured interviews were guided by six prepared questions related to the three variables (See Appendix B). The questionnaire was translated into Chinese and checked for accuracy by the two teachers who were both native speakers of Mandarin Chinese. Before use, the Chinese version of the questionnaire was piloted on three students and then revised based on their feedback. The scales used in the questionnaire are as follows.

WTC in the Classroom Scale: The tool to measure WTC in the classroom was adapted from MacIntyre et al. (2001). The scale was originally created for measuring WTC of French L2 learners and it involved four language skill areas (27 questions): speaking, listening comprehension, reading and writing. Our questionnaire only adapted the speaking questions (8 questions), as this skill was the focus of this study. The questionnaire was translated into Chinese by the first author and then independently back translated by a bilingual colleague. Discrepancies were discussed and a final translation was agreed upon. Participants were asked to rate their WTC in the classroom in various speaking situations from 1 to 5 where $1=$ almost never willing and $5=$ almost always willing. Sum scores were extracted from the completed questionnaire with any missing data being replaced by row means.

Ideal L2 Self \& Ought-to L2 Self Scales: The two scales were from Taguchi et al. (2009). Again, the tool was translated and back translated before the final version was agreed upon using the procedure outlined above. Both sets of 
questions were on a 6-point Likert scale from 1= strongly disagree to 6= strongly agree, which involves ten hypothetical situations associated with the two L2 selves respectively. Sum scores were extracted from the completed questionnaire with missing data replaced by row means.

\section{Data Analysis}

The two statistical methods used in this paper were Correlation and Moderation Analysis. Correlation analysis attempts to quantify the strength of association between two variables on a continuous scale. Pearson's correlation coefficient was used as the data were approximately normally distributed and the relationship was linear. Moderation analysis allows us to look at how a relationship between two variables is influenced by a third variable. Specifically, in this paper we looked at how the chosen major a student is studying in the UK influences (moderates) the relationship between their level of WTC in the classroom and the two motivation measures. Given the fact that a moderation model is just an extension of a multiple regression model the same sets of assumptions apply, linearity was assessed visually, and qqplots were produced to assess the approximate distribution of the residuals. In all cases, these assumptions were found to hold.

Based on the findings from questionnaire data, we interviewed six participants (three English majors and three nonEnglish majors) in person to triangulate findings. The qualitative phase was done to provide corroboration for the quantitative results (Mason, 2006). Interviewees were selected through voluntary sampling, where we sent out interview requests to participants and chose from those who responded to us. In the interviews, the essential concepts in this study (i.e., WTC, ideal L2 self and ought-to L2 self) had been explained to them before they were asked to describe their understanding of each one and how they saw connections between their English WTC and future L2 selves. Prompt questions were therefore formulated and used in interviews (see both English and Chinese versions in Appendix B). Having finished six interviews, we transcribed and translated them into English. Based on the transcription, a thematic content analysis was conducted by two researchers. Individually we took the main steps of 1) familiarizing ourselves with the narrative data; 2) identifying themes from the transcription; 3) selecting relevant quotes with our understanding of the existing literature. The generating themes were then gathered into "larger categories for the purposes of further interpretation and discussion" (Barkhuizen, 2015, p. 100), which in our study were under the categories of future L2 selves, classroom WTC and the connections between them. Having coded the interview data independently, our analyses were compared, and differences were discussed through peer debriefing (Brown, 2004) before we agreed upon the final version.

\section{Results}

\section{Quantitative Findings}

The correlations between the three primary measures collected are given in Table 2. There is a large statistically significant positive correlation between WTC in the classroom and ideal L2 self. In other words, those participants who scored high on WTC in the classroom were also likely to score high on ideal L2 self. There is a small yet statistically significant correlation between WTC in the classroom and ought-to L2 self. This suggests that while there is a relationship between WTC in the class and ought-to L2 self, the relationship between WTC and ideal L2 self is stronger. There is a small and not statistically significant correlation between the two L2 selves, although the p-value was approaching statistical significance $(\mathrm{p}=0.08)$.

Table 2. Correlation matrix of WTC in the classroom and self-motivation measures

\begin{tabular}{llll}
\hline & WTC in the classroom & Ideal L2 self & Ought-to L2 self \\
WTC in the classroom & 1 & & \\
Ideal L2 self & $0.57^{* * *}$ & 1 & 1 \\
Ought-to L2 self & $0.26^{* * *}$ & $0.16^{\mathrm{ns}}$ & 1 \\
\hline
\end{tabular}

$\mathrm{ns}$ for $\mathrm{p}>0.05,{ }^{*}$ for $\mathrm{p} \leq 0.05,{ }^{* *}$ for $\mathrm{p} \leq 0.01,{ }^{* * *}$ for $\mathrm{p} \leq 0.001$

We were interested in whether the participant was studying for an English related major influenced their relationship between WTC in the classroom and the two kinds of language selves. Table 3 shows the relationship between WTC in the classroom and ideal L2 self. We can see that both major and ideal L2 self predict WTC in the classroom. However, the moderation term (or the interaction in more statistical nomenclature) shows that major does not modify the relationship between WTC and ideal L2 self. 
Table 3. The relationship between classroom WTC and ideal L2 self moderated by major

\begin{tabular}{lccc}
\hline & Beta & S.E. Beta & t \\
\hline (Intercept) & 5.92 & 3.16 & $1.87 \mathrm{~ns}$ \\
Major & 5.37 & 6.20 & $0.87^{\mathrm{ns}}$ \\
Ideal L2 self & 0.42 & 0.07 & $6.39^{* * *}$ \\
Major x Ideal L2 self & -0.10 & 0.12 & $-0.85^{\mathrm{ns}}$ \\
\hline
\end{tabular}

Adjusted $R^{2}=0.31$, $\mathrm{ns}$ for $\mathrm{p}>0.05,{ }^{*}$ for $\mathrm{p} \leq 0.05,{ }^{* *}$ for $\mathrm{p} \leq 0.01,{ }^{* * *}$ for $\mathrm{p} \leq 0.001$

Table 4 shows the moderation model describing the relationship between WTC in the classroom major and ought-to L2 self. We can see that all model parameters are highly statistically significant. This indicates that there is a relationship between WTC in the classroom and both explanatory variables (major and ought-to L2 self) and that the moderating effect is also significant.

Table 4. The relationship between classroom WTC and ought-to L2 self moderated by major

\begin{tabular}{lccc}
\hline & Beta & S.E. Beta & t \\
\hline (Intercept) & 14.32 & 2.36 & $6.08^{* * *}$ \\
Major & 0.31 & 0.06 & $5.05^{* * *}$ \\
Ought-to L2 Self & 14.05 & 3.44 & $4.08^{* * *}$ \\
Major x Ought-to L2 self & -0.31 & 0.10 & $-3.29^{* * *}$ \\
\hline
\end{tabular}

Adjusted $R^{2}=0.19, \mathrm{~ns}$ for $\mathrm{p}>0.05, *$ for $\mathrm{p} \leq 0.05, * *$ for $\mathrm{p} \leq 0.01,{ }^{* * *}$ for $\mathrm{p} \leq 0.001$

The moderating effect of the major the student is studying is illustrateed in Figure 1. From this, we can clearly see that among the English majors there is a small negative relationship between WTC in the classroom and ought-to L2 self, while for the non-English majors there is a strong positive relationship.

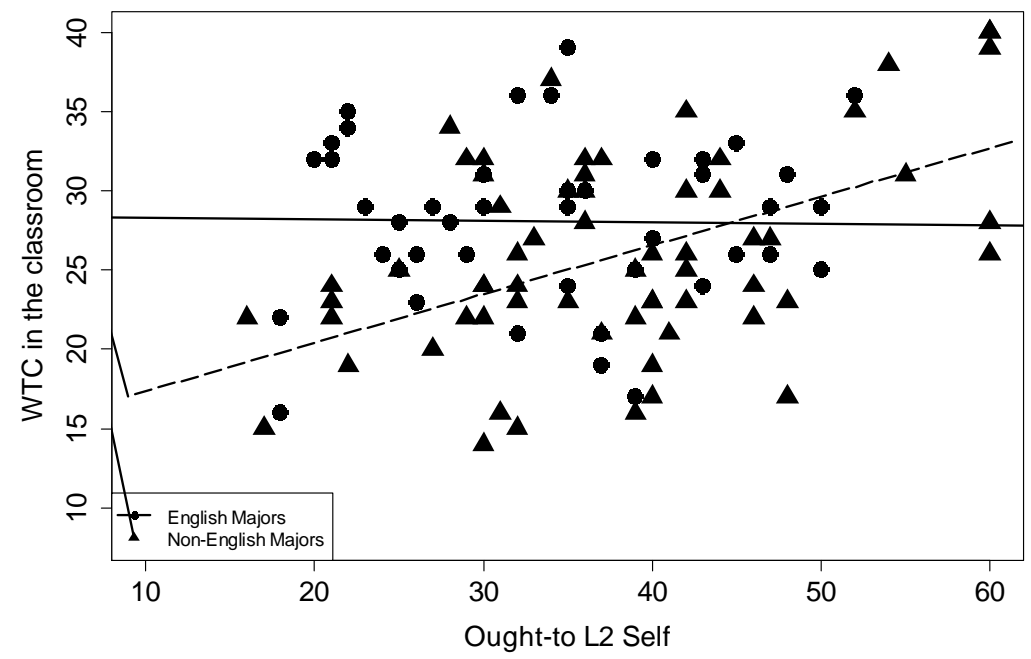

Figure 1. Visualisation of the moderating effect of major on the relationship between classroom WTC and ought-to L2 self

\section{Qualitative Findings}

To further probe the results, six interviews were conducted with three English majors and three non-English majors. The interview data shed light on different perspectives of students viewing their own ideal L2 self, ought-to L2 self and WTC in the classroom. We found that four of six participants reported to be motivated to talk in class more by their ideal L2 self than ought-to L2 self. It was identified that their level of classroom WTC was engendered by desire for progress in career, intercultural communication and desirable friendship, which tend to be in the domain of their ideal L2 self.

Furthermore, from the interviews, we noticed that the two L2 selves can partially overlap with each other. For example, one participant claimed that "I [she] do [does] want (closer to ideal self) to do things expected by my [her] significant others (closer to ought-to self)." The interview data also indicate the differences between English and non-English majors in terms of the role of ought-to L2 self in influencing their WTC in the class. Compared with English majors, interviewees from non-English majors generally demonstrated a stronger ought-to L2 self, which might play a significant part in their L2 learning. External pressures such as family expectations (e.g., "I don't want to disappoint my parents") or work requirements (e.g., "I worry about not getting a decent job") were emphasized as reasons for wanting to improve English and communicating in the classroom, though the tendency of career orientation appeared in both groups. The coding scheme and salient examples of each code can be seen in Table 5 below. 
Table 5. Coding scheme based on interviews

\begin{tabular}{|c|c|c|}
\hline $\begin{array}{l}\text { Key elements in } \\
\text { interview questions }\end{array}$ & Themes identified & Examples \\
\hline \multirow[t]{2}{*}{ WTC in the classroom } & Good level & "I enjoy talking in real situations and solve problems with my peers." (Ming, TESOL) \\
\hline & Moderate level & "Not bad, though I still like writing more." (Sisci, Translation) \\
\hline \multirow[t]{3}{*}{ Ideal L2 self } & Native-like language features & $\begin{array}{l}\text { "I want to sound as good as native speakers." (Kalsy, Media) } \\
\text { "I want the British accent like my friend Bianca!" (Ming, TESOL) }\end{array}$ \\
\hline & Career-related aspirations & $\begin{array}{l}\text { "Good English is essential for a good language teacher." (Shin, TESOL) } \\
\text { "It's very important for me as a future translator. I want to be better." (Sisci, Translation) }\end{array}$ \\
\hline & Interest & "Friends is my favourite TV show, I want to speak like them." (Bella, Data Science and Analytics) \\
\hline \multirow[t]{3}{*}{$\begin{array}{l}\text { The connections } \\
\text { between ideal L2 self } \\
\text { and WTC in the } \\
\text { classroom }\end{array}$} & Practice for progress in career & $\begin{array}{l}\text { "To speak English more is to practice the skill which will help my career." (Shin, TESOL) } \\
\text { "To be a translator requires me to speak fluent English. I'd say because of this I'll try to speak } \\
\text { more in the class." (Sisci, Translation) }\end{array}$ \\
\hline & Intercultural communication & $\begin{array}{l}\text { "Talking to people from different cultural backgrounds makes me feel good." } \\
\text { (Hong, International Business) }\end{array}$ \\
\hline & Desirable friendship & $\begin{array}{l}\text { "Communication helps build connections between me and my classmates in the class." } \\
\text { (Sisci, Translation) }\end{array}$ \\
\hline \multirow[t]{3}{*}{ Ought-to L2 self } & Family expectations & $\begin{array}{l}\text { "I grew up with a lot of opinions from my parents." (Hong, International Business) } \\
\text { "I don't want to disappoint my parents." (Kalsy, Media) }\end{array}$ \\
\hline & Work requirements & $\begin{array}{l}\text { "I worry about not getting a decent job or meeting the expectations of companies I like." (Bella, } \\
\text { Data Science and Analytics) }\end{array}$ \\
\hline & $\begin{array}{l}\text { Difficulty in differentiating the } \\
\text { ideal L2 self and ought-to L2 } \\
\text { self }\end{array}$ & $\begin{array}{l}\text { "I can't really distinguish these two selves. Sometimes it seems like my ideal L2 self is my ought-to } \\
\text { L2 self." (Hong, International Business) } \\
\text { "I do want to do things expected by my significant others though." (Ming, TESOL) }\end{array}$ \\
\hline \multirow{2}{*}{$\begin{array}{l}\text { The connections } \\
\text { between ought-to L2 } \\
\text { self and WTC in the } \\
\text { classroom }\end{array}$} & Pressure & $\begin{array}{l}\text { "Speaking English here is a natural thing to do. But still, sometimes I feel it's a task to be } \\
\text { accomplished." (Bella, Data Science and Analytics) } \\
\text { "Sometimes I answer questions in the class because I feel the teacher wants me to." (Shin, TESOL) }\end{array}$ \\
\hline & Prevention of failure & $\begin{array}{l}\text { "I'll worry I can't get a good job if I don't work hard enough in English and have a good level. It is } \\
\text { kind of pushing me to speak." (Kalsy, Media) }\end{array}$ \\
\hline
\end{tabular}




\section{Discussion}

\section{The Relationship between Future L2 Selves and L2 WTC in the Classroom}

As we discussed, a statistically significant positive correlation was found between ideal L2 self and L2 WTC in the classroom among our participants. This indicates that on average the stronger one's ideal L2 self is, the more desire one has to talk in L2 in the classroom. The association between ideal L2 self and L2 WTC in this study is consistent with the results from Öz (2016), Öz et al. (2015) and Munezane (2013). According to Ushioda and Dörnyei (2009), future L2 selves often generate differential levels of motivation, and this is clearly borne out in our results. Ideal L2 self is usually considered a more powerful source of L2 motivation and thus likely to encourage motivated learning behaviour (ibid.). Furthermore, since this study was conducted in the UK, an English-speaking environment might also have brought positive changes in their future L2 selves. Sisci, a Translation student, gave an example:

When I was studying in China, I forced myself to speak English because I feared I would fail my IELTS speaking test if I did not, and that was something I should do. However, in the UK, the good phenomenon of workshops made me realise that I actually enjoy speaking the language, so now I feel that is something I want to do.

Sisci's attitude reflects a change under a different learning environment, which switches from meeting exam requirements (closer to ought-to L2 self) to gaining enjoyment in the language (closer to ideal L2 self). The alteration is in line with Fryer and Roger (2018) where more strengthened ideal L2 selves emerged from L2 learners due to overseas learning experiences. In an English-speaking academic context, there are also other factors that might increase the strength of their ideal L2 self and their desire for communication. For example, students are able to build a clearer ideal L2 self-image by adding specific desirable language features through communication with native English speakers (e.g., "I want to have the British accent like my friend Bianca"), which they might not be able to do in an EFL academic context considering limited authentic language resources around. In terms of ought-to L2 self and L2 WTC in the classroom, however, they were not strongly correlated in this study, which seems contradictory with the study of Taguchi et al. (2009) that pointed out the motivational role of ought-to L2 self. This unexpected finding may result from the background of our participants. Some previous studies have found the strength of ought-to L2 self is likely reduced as people become older, for example, high school students may have a stronger sense of ought-to L2 self than university counterparts (e.g., Csizér \& Kormos, 2009; Papi \& Teimouri, 2012). This suggests the issue of age may explain a low effect of ought-to L2 self on L2 WTC in our participants who were postgraduate students, with average age above 23 years old, though it is difficult to draw any firm conclusions.

Some of the interview data, however, appeared to show that the role of ought-to L2 self cannot be underestimated in the study. As claimed by Dörnyei (2009), ought-to L2 self is closely associated with expectations from significant others, such as employers or family members. While the quantitative results did not reveal a significant relationship between ought-to L2 self and L2 WTC, interestingly, the interview data did indicate some participants were confused by the boundary between the two L2 selves. When Hong (a non-English major) was asked to describe her two L2 selves, she said, "I grew up with a lot of opinions from my parents. To be honest, I can't really distinguish these two selves. Sometimes it seems like my ideal L2 self is my ought-to L2 self." Regarding Hong's doubt, one explanation for this confusion may be that, as she grew up, her ought-to L2 self (i.e., hopes from parents) started to become internalized in her ideal L2 self (i.e., hopes of her own). Her doubt shows that what was expected by her family gradually grew into her domain of ideal L2 self and might become fully internalized. This overlap between one's own desires and those of parents is revealing. Perhaps L2MSS does not neatly hold over to the Chinese context without the need for modification.

The evidence above adds to the argument that the two L2 selves are not two entirely separate components but interact with each other. Previous studies have also identified the links between them. Peng (2015) and Csizér and Kormos (2009) found that students' ought-to L2 self might affect their ideal L2 self in the way ought-to L2 self has a tendency of becoming part of ideal L2 self under certain conditions. This reflects the idea of internalization (i.e., from ought-to to ideal L2 self), which was similarly illustrated by Magid (2009). He found that family's expectations in the Chinese context are central to make one's ought-to L2 self and ideal L2 self difficult to distinguish. The potential process of internalization between future L2 selves might also relate to the concept of own/other standpoints (Teimouri, 2017). To be specific, ought-to L2 self can stem from others' expectations (ought-to L2 self/other), but they might gradually develop into one's own true expectations towards oneself. In other words, the external expectations could become part of a person's ought-to L2 self/own or even ideal L2 self/own, depending on to what extent they have become internalized. The discussion about the complexity between future L2 selves in both previous research and this study suggests that there might be more room for future investigations of the concept of internalization and meanwhile the essential role of outside expectations like family on Chinese students in the language learning journey.

\section{Differences Between English Majors and Non-English Majors}

Our study identified that a participant's major (English or non-English related) moderates their ought-to L2 self and L2 WTC in the classroom. For non-English majors, a stronger ought-to L2 self contributes to a higher level of their 
classroom WTC, but WTC of English majors are unlikely to be influenced by the strength of their ought-to L2 self. This finding underlines the motivational impetus of ought-to L2 self which few previous studies have identified (e.g., Fryer \& Roger, 2018). The interview data further indicate different views from the two groups towards ought-to L2 self. Whereas two of three English-major interviewees regarded ought-to L2 self as a less influential element in the language learning, one non-English major student admitted its importance in "pushing me [her] to speak". From interviews, Hong and Kalsy (non-English majors) mentioned that meeting family expectations (e.g., "I don't want to disappoint my parents"; "I grew up with a lot of opinions from my parents") and future work requirements (e.g., "I worry about not getting a decent job") were the main motivation for them to learn English. Meanwhile, Bella (a non-English major) said, for her, using English in the academic environment to communicate sometimes seemed "a task to be accomplished", and she somehow felt pressure if she did not. English-major interviewees, however, tend to demonstrate less concern about their ought-to L2 self. For example, though career orientation was identified in the interviews with both groups, the motivation of English majors seems to reflect in a promotional nature (closer to ideal L2 self) (e.g., to be a good English teacher; to be a better English translator) rather than a preventive nature (closer to ought-to L2 self). In other words, English-related majors tend to be motivated to learn English more for fulfilling their own aspirations than for the fear of facing negative outcomes. This shows the divisions of the influence of ought-to L2 self between English and non-English majors in their learning behaviour.

Nevertheless, some of our interview data, as well as several previous studies, appear to show a few contradictions. Though the interview data suggest that ought-to L2 self does not seem to explain English majors' WTC, Shin (an English major) stated, "sometimes I answer questions in the class because I feel the teacher wants me to." This indicates that regardless of the difference in the academic background, two groups of students might both share the feeling of external pressure in the classroom, which could have given them a sense of obligation to speak more. In contrast to our findings, Lee and Lee (2020) failed to find a positive effect of ought-to L2 self in enhancing WTC of non-English major university students. Additionally, You et al. (2016) suggest that instead of ought-to L2 self, what degree subject influences may be the learner's ideal L2 self. They argue that English-related degree courses can stimulate students to build a clearer image of ideal L2 self, as they provide more specialized and fruitful resources about the English language than non-English major courses (ibid.). In fact, the distinctions between English and non-English majors in this issue have been so far published in only a limited number of empirical studies. The potential influences of different academic backgrounds this study highlights, therefore, might conceivably provoke further insights into the interconnections between motivating future L2 selves and classroom WTC across various contexts.

\section{Conclusion}

The current study examined the role of ideal L2 self and ought-to L2 self in L2 WTC in the classroom among Chinese university students studying in the UK. We found that a strong ideal L2 self is associated with heightened WTC in the classroom. Again, this finding highlights the connections between future L2 selves and WTC. Furthermore, it was identified that ought-to L2 self can be a potentially important influence on ideal L2 self, suggesting a previously less highlighted interactive complexity between future L2 selves. Additionally, our results indicate that the academic background of students tends to be influential to their future L2 selves and WTC in the classroom. It was found that whereas ought-to L2 self appears to encourage L2 WTC of non-English majors, this relationship was not reflected in English majors. This finding emphasizes the role of ought-to L2 self in different majors and therefore their learning behaviour.

\section{Recommendations}

The second-phase interviews suggest the issue of internalization between the two L2 selves, showing that external pressure can help internalize one's ought-to L2 self into the ideal L2 self. This process not only underlines the dynamic nature of future L2 selves but also reveals the complex layers within motivating L2 selves which might generate motivation of different levels. These potential interactions would allow room for future research on how they might impact motivated learning behaviours like L2 WTC in different learning contexts. Moreover, the finding of the discrepancy between English and non-English related majors indicates that language courses at university level may take different teaching approaches to students from various academic subjects in order to better encourage their WTC and help different learner groups to achieve language progress. For non-English related majors, for example, it might be useful for teachers to understand how they link English with their future obligations and involve relevant activities in the class (e.g., designing an English CV). In particular, for language educators this finding highlights the significance of proper classroom activities in relation to students' learning behaviour. Especially among those who are less engaged or have less chances to communicate in L2 outside the class (e.g., in a non-L2 speaking learning environment), it would be important to consider "how to build communication into a realistic goal" in the class so that students might be more willing to engage (Yashima, 2020, p. 216).

\section{Limitations and Directions for Future Research}

The study, nevertheless, has limitations that future research can profitably address. One limitation is demographic diversity, given the majority of our participants were females. This is difficult to address as most of the Chinese 
students studying English related majors in the UK are female. However, this imbalance may have affected the measured results of the strength of the three key variables due to the possible gender difference regarding our topic. Moreover, since classroom WTC is a dynamic and complex phenomenon, more research design of qualitative aspects could be involved, such as classroom observations, to capture WTC fluctuations in real time. The non-traditional CDST approach can also be employed in the future WTC studies which allows for more contextual influences in the research. Furthermore, it would be interesting to conduct a more fully featured study which explores the interconnectedness between more factors concerned with WTC such as anxiety or confidence. This could help explore more potential interactions among WTC and individual differences, which might bring theoretical or pedagogical implications. To understand individual differences more in depth, future investigations can address the topic in different L2 learner groups or learning contexts. Nevertheless, whatever the case may be, probing the theory behind and finding mechanisms to increase classroom WTC among different groups of students is an important endeavour as we move forwards into an increasingly interconnected and globalized world.

\section{References}

Bao, D. (2014). Understanding silence and reticence: Ways of participating in second language acquisition. Bloomsbury.

Barkhuizen, G. (2015). Narrative knowledging in second language teaching and learning contexts. In A. De Fina, \& A. Georgakopoulou (Eds.), Handbook of narrative analysis (pp. 97-115). Wiley-Blackwell.

Boo, Z., Dörnyei, Z., \& Ryan, S. (2015). L2 motivation research 2005-2014: Understanding a publication surge and a change landscape. System, 55, 145-157.

Brown, J. D. (2004). Research methods for applied linguistics: Scope, characteristics, and standards. In A. Davies, \& C. Elder (Eds.), The handbook of applied linguistics (pp. 476-500). Blackwell.

Bukhari, S. F., \& Cheng, X. (2017). To do or not to do, willingness to communicate in the ESL context: Pakistani students are highly willing to communicate in English in Canada. English Today, 33(1), 36-42.

Cameron, D. (2015). 'In New Zealand I feel more confidence': The role of context in the willingness to communicate (WTC) of migrant Iranian English language learners. International Journal of English Studies, 15(2), 61-80.

Council of Europe. (2001). Common European Framework of Reference for Languages: Learning, teaching, assessment. Cambridge University Press.

Csizér, K., \& Kormos, J. (2009). Learning experiences, selves and motivated learning behaviour: A comparative analysis of structural models for Hungarian secondary and university learners of English. In Z. Dörnyei \& E. Ushioda (Eds.), Motivation, language identity and the L2 self (pp. 98-119). Multilingual Matters.

Csizér, K., \& Lukács, G. (2010). The comparative analysis of motivation, attitudes and selves: The case of English and German in Hungary. System, 38, 1-13

Dörnyei, Z. (2005). The Psychology of the language learner: Individual differences in second language acquisition. Lawrence Erlbaum Associates Publishers.

Dörnyei, Z. (2009). The L2 Motivational Self System. In Z. Dörnyei \& E. Ushioda (Eds.), Motivation, language identity and the L2 self (pp. 9-42). Multilingual Matters.

Dörnyei, Z., \& Ushioda, E. (2011). Teaching and Researching Motivation. Pearson Education.

Fryer, M., \& Roger, P. (2018). Transformations in the L2 self: Changing motivation in a study abroad context. System, 78, $159-172$.

Higgins, T. (1987). Self-discrepancy: A theory relating self and affect. Psychological Review, 94(3), 19-40.

Kang, S.-J. (2005). Dynamic emergence of situational willingness to communicate in a second language. System, 33(2), 277-292.

Khajavy, G. H., Ghonsooly, B., Fatemi, A. H., \& Choi, C. W. (2016). Willingness to communicate in English: A microsystem model in the Iranian EFL classroom context. TESOL Quarterly, 50(1), 154-180.

Lamb, M. (2007). The impact of school on EFL learning motivation: An Indonesian case study. TESOL Quarterly, 41(4), 757-780.

Lamb, M. (2012). A self system perspective on young adolescents' motivation to learn English in urban and rural settings. Language Learning, 62(4), 997-1023.

Lanver, U. (2016). Lots of selves, some rebellious: Developing the self discrepancy model for language learners. System, $60,79-92$. 
Lee, J. S., \& Lee, K. (2020). Role of L2 motivational self system on willingness to communicate of Korean EFL university and secondary students. Journal of Psycholinguistic Research, 49, 147-161.

Lin, Y. (2019). Taiwanese EFL learners' willingness to communicate in English in the classroom: Impacts of personality, affect, motivation, and communication confidence. The Asia-Pacific Educational Researcher, 28(2), 101-113.

MacIntyre, P. D., Clément, R., Dörnyei, Z., \& Noels, K. A. (1998). Conceptualizing willingness to communicate in a L2 confidence and affiliation. The Modern Language Journal, 82(4), 545-562.

MacIntyre, P. D., Baker, S. C., Clement, R., \& Conrod, S. (2001). Willingness to communicate, social support and languagelearning orientations of immersion students. Studies in Second Language Acquisition, 23(3), 369-388.

MacIntyre, P. D., Baker, S., Clément, R., \& Donovan, L. A. (2003). Talking in order to learn: Willingness to communicate and intensive language programs. Canadian Modern Language Review, 59(4), 589-608.

MacIntyre, P. D., \& Legatto, J. J. (2011). A dynamic system approach to willingness to communicate: Developing an idiodynamic method to capture rapidly changing affect. Applied Linguistics, 32(2), 149-171.

Magid, M. (2009). The L2 Motivational Self System from a Chinese perspective: A mixed methods study. Journal of Applied Linguistics, 6(1), 69-90.

Mason, J. (2006). Six strategies for mixing methods and linking data in social science research. Working Papers.

Munezane, Y. (2013). Attitudes, affect and ideal L2 self as predictors of willingness to communicate. EUROSLA Yearbook, $13(1), 176-198$.

Nakamura, T. (2019). Understanding motivation for learning languages other than English: Life domains of L2 self. System, 82, 111-121.

Oyserman, D., \& James, L. (2009). Possible selves: From content to process. In K. Markman, W. Klein \& J. Suhr (Eds.), The handbook of imagination and mental stimulation (pp. 373-394). Psychology Press.

Öz, H. (2016). Role of the ideal L2 self in predicting willingness to communicate of EFL students. In İ. H. Mirici, İ. H. Erten, H. Öz \& I. Vodopija-Krstanovic (Eds.), Research papers as an additional language (pp.163-182). Faculty of Humanities and Social Research.

Öz, H., Demirezen, M., \& Pourfeiz, J. (2015). Willingness to communicate of EFL learners in Turkish context. Learning and Individual Differences, 37, 269-275.

Papi, M. (2010). The L2 Motivational Self System, L2 anxiety, and motivated behaviour: A structural equation modelling approach. System, 38(3), 467-479.

Papi, M., \& Teimouri, Y. (2012). Dynamics of selves and motivation: A cross-sectional study in the EFL context of Iran. International Journal of Applied Linguistics, 22(3), 287-309.

Pawlak, M., \& Mystkowska-Wiertelak, A. (2015). Investigating the dynamic nature of L2 willingness to communicate. System, 50, 1-9.

Peng, J. (2007). Willingness to communicate in an L2 and integrative motivation among college students in an intensive English language program in China. University of Sydney Papers in TESOL, 2, 33-59.

Peng, J. (2015). L2 Motivational Self System, attitudes, and affect as predictors of L2 WTC: An imagined community perspective. The Asia-Pacific Education Researcher, 24(2), 433-443.

Peng, J. (2019). The roles of multimodal pedagogic effects and classroom environment in willingness to communicate in English. System, 82, 161-173.

Peng, J., \& Woodrow, L. (2010). Willingness to communicate in English: A model in the Chinese EFL classroom context. Language Learning, 60(4), 834-876.

Peng, J., Zhang, L., \& Chen, Y. (2017). The mediation of multimodal affordances on willingness to communicate in English as a foreign language classroom. TESOL Quarterly, 51(2), 302-331.

Riazi, A. M., \& Candlin, C. N. (2014). Mixed-methods research in language teaching and learning: Opportunities, issues and challenges. Language Teaching, 47(2), 135-173.

Shao, Q., \& Gao, X. (2016). Reticence and willingness to communicate (WTC) of East Asian language learners. System, 63,115-120.

Su, M., \& Harrison. M. L. (2016). Being wholesaled: An investigation of Chinese international Students' Higher Education Experiences. Journal of International Students, 6(4), 905-919. 
Taguchi, T., Magid, M., \& Papi, M. (2009). The L2 motivational self system among Japanese, Chinese and Iranian learners of English: A comparative study. In Z. Dörnyei \& E. Ushioda (Eds.), Motivation, language identity and the L2 self (pp. 66-97). Multilingual Matters.

Teimouri, Y. (2017). L2 selves, emotions and motivated behaviours. Studies in Second Language Acquisition, 39(4), 681709.

Ushioda, E. (2011). Language learning motivation, self and identity: Current theoretical perspectives. Computer Assisted Language Learning, 24(3), 199-210.

Ushioda, E., \& Dörnyei, Z. (2009). Motivation, language identities and the L2 self: A theoretical overview. In Z. Dörnyei \& E. Ushioda (Eds.), Motivation, language identity and the L2 self (pp. 1-8). Multilingual Matters.

Wen, W. P., \& Clément, R. (2003). A Chinese conceptualisation of willingness to communicate in ESL. Language Culture and Curriculum, 16(1), 18-38.

Xie, X. (2010). Why are students quiet? Looking at the Chinese context and beyond. ELT Journal, 64(1), 10-20.

Yashima, T. (2020). L2 motivation and willingness to communicate. In M. Lamb, K. Csizér, A. Henry \& S. Ryan (Eds.), The Palgrave handbook of motivation for language learning (pp. 203-223). Palgrave Macmillan.

Yashima, T., MacIntyre, P., \& Ikeda, M. (2018). Situated willingness to communicate in an L2: Interplay of individual characteristics and context. Language Teaching Research, 22(1), 115-137.

You, C. J., Dornyei, Z., \& Csizér, K. (2016). Motivation, vision, and gender: A survey of learners of English in China. Language Learning, 66(1), 94-123.

Yue, Z. (2014). Chinese university students' willingness to communicate in the L2 classroom: The complex and dynamic interplay of self-concept, future self-guides and the sociocultural context. In K. Csizér \& M. Magid (Eds.), The impact of self-concept on language learning (pp. 250-267). Multilingual Matters.

Zhu, H. (2016). Identifying research paradigms. In H. Zhu (Ed.), Research methods in intercultural communication: $A$ practical guide (pp. 1-22). Wiley Blackwell. 
Appendix A: Questionnaire (English and Chinese versions)

\section{English version}

Part 1

Please provide your personal information in the blank spaces.

1. Name (optional):

2. Gender: $\square$ male $\square$ female $\square$ prefer not to say

3. Age:

4. How long have you spent studying/working in English-speaking countries? If doing Masters in the UK is your first experience, please write " 1 year".

5. What is your current major?

6. English proficiency (IELTS CEFR): Part 2

Please indicate in the space provided the frequency you speak English in each situation.

$1=$ Almost never willing $2=$ Sometimes willing $3=$ Willing half of the time

4 = Usually willing $5=$ Almost always willing

Please note: The following situations happen inside the classroom.

Speaking in class, in English

1. Speaking in a group about your summer vacation.

2. Speaking to your teacher about your homework assignment.

3. A stranger enters the room you are in, how willing would you be to have a conversation if he talked to you first?

4. You are confused about a task you must complete, how willing are you to ask for instructions/clarification?

5. Talking to a friend while waiting in line.

6. How willing would you be to be an actor in a play?

7. Describe the rules of your favourite game.

8. Play a game in English, for example Monopoly.

A.

Part 3

Please indicate the degree that you agree with the following statements by using scales 1-5.

1 = Strongly disagree 2 = Disagree 3 = Slightly disagree

$4=$ Slightly agree $5=$ Agree $6=$ Strongly agree

1. I can imagine myself living abroad and having a discussion in English.

2. I can imagine myself studying in a university where all my courses are taught in English.

3. Whenever I think of my future career, I imagine myself using English.

4. I can imagine a situation where I am speaking English with foreigners.

5. I can imagine myself speaking English with international friends or colleagues.

6. I can imagine myself living abroad and using English effectively for communicating with the locals.

7. I can imagine myself speaking English as if I were a native speaker of English.

8. I imagine myself as someone who is able to speak English.

9. I can imagine myself writing English e-mails/letters fluently.

10. The things I want to do in the future require me to use English.

B.

Please indicate the degree that you agree with the following statements by using scales 1-5.

1 = Strongly disagree. 2 = Disagree 3 = Slightly disagree

$4=$ Slightly agree $\quad 5=$ Agree $\quad 6=$ Strongly agree

1. I study English because close friends of mine think it is important.

2. Learning English is necessary because people surrounding me expect me to do so.

3. I consider learning English important because the people I respect think that I should do it.

4. If I fail to learn English I'll be letting other people down.

5. Studying English is important to me in order to gain the approval of my peers/teachers/family/boss.

6. I have to study English because, if I do not study it, I think my parents will be disappointed with me.

7. My parents believe that I must study English to be an educated person.

8. Studying English is important to me because an educated person is supposed to be able to speak English.

9. Studying English is important to me because other people will respect me more if I have a knowledge of

English.

10. It will have a negative impact on my life if I don't learn English. 


\section{Chinese version}

请填入个人信息。

$$
\text { 第一部分 }
$$

1. 名字 (选填):

2. 性别: 口男口女口不愿透露

3. 年龄:

4. 你有多少年在英语国家工作或学习的经历？如果在英国的硕士研究生学习是你的第一次经历, 请写“1 年”:

5. 你现在的专业是什么?

6. IELTS CEFR 水平（如 $\mathrm{B} 2, \mathrm{C} 1, \mathrm{C} 2$ ) :

以下是发生在英国学术环境课堂内的几种情形, 请提供在每个情况下你愿意使用英语交谈的程度。

$1=$ 从来不愿意

$2=$ 有时愿意

$3=$ 一半的时间都愿意

$4=$ 通常愿意

$5=$ 总是愿意

1. 在小组开口讨论关于你的假期发生的事。

2. 主动与老师讨论作业。

3. 如果一个陌生人进入你所在的教室, 主动与你说话, 你有多愿意和他展开交谈呢?

4. 你不太理解老师给出的作业要求, 你会有多愿意主动进一步询问呢?

5. 在排队等待某事 (如排队问问题) 的时候与你的朋友用英文谈话。

6. 如果课堂需要表演一个情景剧, 你有多愿意参与?

7. 你有多愿意用英语谈论你最喜欢游戏的规则?

8. 用英语来玩如 ‘大富翁”一类的游戏。

A. 请根据以下的指标 1-6, 给出你的赞同程度。

$1=$ 非常不同意

$2=$ 不同意

$3=$ 有一点不同意

$4=$ 有一点同意

$5=$ 同意

$6=$ 非常同意

1. 我会想象自己未来在国外继续学习或生活, 并且用英语和同学朋友交谈。

2. 我会想象自己在一个全英文授课的坏境里顺利地学习。

3. 无论何时我想到我未来的工作, 我想象这份工作需要使用英语。

4. 我会想象自己与外国人用英语交谈的画面。

5. 我会想象自己用英语和非英语国家的朋友或工作伙伴交流。

6. 我会想象自己在国外生活, 并且使用英语和当地人进行有效的沟通交流。

7. 我会想象自己能像一个英语母语使用者那样流利地使用英语。

8. 我会想象自己是一个能说英语的人。

9. 我会想象自己流利地写英文电子邮件或信件。

10. 我未来想做的事情要求我要会说英语。

B. 请根据以下的指标 1-6, 给出你的赞同程度。

$1=$ 非常不同意

$2=$ 不同意

$3=$ 有一点不同意

$4=$ 有一点同意

$5=$ 同意

$6=$ 非常同意

1. 我学英语因为我亲近的朋友们都觉得英语很重要。

2. 在我身边的人们期望我学英语, 所以我认为英语学习是必需的。

3. 我觉得英语学习重要是因为某些我尊敬的人认为我应该要学它。

4. 如果我不学习英语, 我会让某些人失望。

5. 为了能到我的同辈 / 老师 / 家人 / 老板的认可, 学习英语对于我来说很重要。

6. 我必须学英语, 因为如果我不学, 我觉得我父母会对我失望。

7. 我父母认为, 学习英语是受过良好教育的标签, 所以我必须学习英语。

8. 学习英语对我很重要, 因为一个受过良好教育的人应该要会讲英语。

9. 学习英语对我很重要, 因为如果我有英语相关的知识, 别人会更加尊重我。

10.如果我不学习英语, 这可能会对我的生活带来消极的影响。 
Appendix B: Prompt questions in semi-structured interviews

1. How will you describe your level of willingness to communicate in English? 你如何描述自己的英语沟通意愿程度?

2. How will you describe your ideal and ought-to L2 self? 你如何理解自己的理想二语自我和应该二语自我?

3. How do you relate English to your future? 你从那些方面把英语和你的未来挂钩?

4. Have you seen any relation between your desire to speak in the classroom and your ideal L2 self or ought-to L2 self? 你觉得你在课堂中说英语的欲望和自己的理想二语自我或应该二语自我有任何关联吗?

5. Which self do you think motivates you more in WTC, the ideal L2 self or ought-to L2 self? 你觉得理想二语自我和应该二语自我哪个对你的英语沟通意愿有更强的促进作用?

6. What outside factors influence you most in your English learning? 你的英语学习受哪些外界因素影响最多? 